\title{
UJI TOKSISITAS EKSTRAK JERUK LIMAU (CITRUS AMBLYCARPA) TERHADAP LARVA NYAMUK AEDES AEGYPTI
}

\author{
Rima Pertiwi Br Sembiring ${ }^{1}$, Arian Risky Yafdas $^{2}$, Claudia Tanamal ${ }^{3}$, Erwin Sopacua ${ }^{4}$ \\ 1,2,3,4Program Studi Pendidikan Dokter, Fakultas Kedokteran, Universitas Prima Indonesia \\ rimapertiwi67@gmail.com
}

\begin{abstract}
Abstrak
Penelitian ini bertujuan untuk mengetahui uji efek ekstrak jeruk limau (citrus amblycarpa) terhadap larva nyamuk aedes aegypti guna mengetahui tingkat toksisitas berdasarkan waktu (0 Menit, 30 Detik, 1 Menit, 5 Menit, 15 Menit, 30 Menit, 60 Menit, 90 Menit dan 120 Menit) dan berdasarkan konsentrasi ekstrak yang diberikan (0\%, 25\%, 50\%, 75\%, dan $100 \%)$. Rancangan penelitian yang digunakan adalah the post test only controlled group design. Rancangan ini digunakan karena tidak dilakukannya pretest terhadap sampel yang akan digunakan. Peneliti melakukan pemilihan secara acak pada kelompok eksperimen maupun kelompok control, dengan cara metode purposive sampling. Cara melakukan uji toksisitas ini adalah dengan cara memasukkan konsentrasi ekstrak jeruk limau yang sudah ditentukan berdasarkan tingkat konsentrasinya kedalam wadah yang berisi larva nyamuk aedes aegypti didalamnya. Metode pengolahan data yang dipilih adalah Mann-whitney dalam penelitian ini, menunjukkan bahwa terdapat perbedaan yang signifkan pada persentase larva yang mati setelah 30 menit pemberian ekstrak etanol kulit jeruk limau (Nilai $P=0.007$ ), begitu juga setelah 60 menit (Nilai $P=0.021), 90$ menit (Nilai $P=0.024)$, dan 120 menit (Nilai $P=0.014)$. Tingkat toksisitas ekstrak jeruk limau terhadap waktu dan konsentrasi yaitu pada konsentrasi tertinggi $100 \%$ setelah 30 menit pemberian ekstrak.
\end{abstract}

Kata Kunci : Jeruk Limau (Citrus Amblycarpa), Larva Nyamuk Aedes Aegypti, Toksisitas

\begin{abstract}
This study aims to determine the effect test of citrus amblycarpa extract on aedes aegypti larvae in order to determine the toxicity based on time ( 0 minutes, 30 seconds, 1 minute, 5 minutes, 15 Minutes, 30 Minutes, 60 Minutes, 90 Minutes and 120 Minutes) and based on the concentration of the extracts given (0\%, 25\%, 50\%, $75 \%$, and $100 \%)$. The research design used was the post test only controlled group design. This design is used because it does not pretest the sample to be used. The researcher made a random selection in the experimental group and the control group, by means of the purposive sampling method. The way to do this toxicity test is by entering the concentration of lime extract that has been determined based on its concentration level into a container containing the Aedes aegypti mosquito larvae in it. The data processing method chosen was MannWhitney in this study, showing that there was a significant difference in the percentage of larvae that died after 30 minutes of giving the ethanol extract of lime peel ( $P$ value $=0.007)$, as well as after 60 minutes ( $P$ value $=0.021$ ), 90 minutes $(P$ value $=0.024)$, and 120 minutes $(P$ value $=0.014)$. The level of toxicity of the lime extract against time and concentration was at the highest concentration of $100 \%$ after 30 minutes of giving the extract.
\end{abstract}

Keywords : Citron (Citrus Amblycarpa), Mosquitoes Larvae Aedes Aegypti, Toxicity 


\section{PENDAHULUAN}

Demam Berdarah Dengue (DBD) adalah penyakit infeksi virus demam dengue dengan gejala klinis demam, nyeri otot, dan nyeri sendi yang disertai ruam, leukopenia, limfadenopati, trombositopenia, dan diatesis hemoragik ${ }^{(1)}$. DBD adalah penyakit yang disebabkan oleh virus arbovirus (artho podborn virus) dan ditularkan oleh gigitan nyamuk genus aedes terutama pada aedes aegypti dan aedes albopictus. Terjadi perembesan plasma yang ditandai dengan adanya peningkatan hematokrit dialami pada penyakit DBD. Sifat nyamuk senang tinggal pada genangan air yang jernih(2). Telur nyamuk dapat bertahan selama berbulan-bulan dengan suhu 20$42^{\circ} \mathrm{C}$. Untuk menjadi nyamuk dewasa, memerlukan waktu 9 hari. Setelah ia menjadi nyamuk dewasa yang sudah dapat menghisap darah selama 3 hari lamanya, nyamuk dewasa dapat menghasilkan telur sebanyak 100 butir $^{(3)}$.

Peningkatan kasus DBD setiap tahunnya berkaitan dengan sanitasi lingkungan sekitarnya. Dengan adanya tempat perindukan bagi nyamuk betina yaitu wadah yang berisi air jernih (seperti bak mandi, tempat penampungan air, kaleng bekas, aliran sungai yang penuh dengan sampah, dll) ${ }^{(4)}$.

Ekstrak jeruk limau (citrus amblycarpa) adalah salah satu bahan yang ramah lingkungan untuk membasmi nyamuk aedes aegypti. Jeruk limau (citrus amblycarpa) memiliki zat minyak atsiri.

Minyak atsiri terbukti dapat membuat serangga enggan untuk mendekat, karna minyak atsiri memiliki bau yang khas dan menyengat. Tak kala, minyak atsiri sering dijadikan bibit parfum $\left({ }^{5}\right.$. Sebab itu, pada penelitian ini akan dilakukan pengujian seberapa besar tingkat toksisitas ekstrak jeruk limau (citrus amblycarpa) yang dapat menyebabkan mortalitas larva nyamuk aedes aegypti.

\section{METODE}

Rancangan penelitian yang digunakan adalah thepost test only controlled group design. Rancangan ini digunakan karena tidak dilakukannya pretest terhadap sampel yang akan digunakan. Peneliti melakukan pengambilan sampel dengan metode purposive sampling.

Ekstraksi dilakukan di Laboratorium Mikrobiologi Universitas Prima Indonesia pada tanggal 30 Juni 2020 sampai dengan 10 Juli 2020, dengan waktu maserasi selama 1 minggu. Sampel pada penelitian ini adalah jeruk limau (Citrus Amblycarpa) yang didapat dari Perkebunan di Desa Namu ukur utara Kabupaten Langkat Provinsi
Sumatera Utara dan Larva nyamuk Aedes Aegypti dibeli dari laboratorium Universitas Sumatera Utara.

Alat yang digunakan pada penelitian ini adalah blender elektrik, rotary evaporator, incubator untuk larva nyamuk, gelas ukur, pipet tetes, piring petri, saringan whatman no 1 . Bahan yang digunakan adalah kulit jeruk limau (citrus amblycarpa) 800 gram, larva aedes aegypti 80 , Alumunium foil, dan aquabidest 8L.

\section{Pembuatan Ekstraksi}

Kulit jeruk dicuci perlahan di bawah air keran yang mengalir dan dibilas oleh air steril. Keringkan pada suhu kamar $\left(30^{\circ} \mathrm{C}\right)$ selama dua hari. Setelah itu dihaluskan menjadi bubuk halus menggunakan blender elektrik. Hasil penggilingan disimpan dalam botol kedap udara. Kemudian serbuk ditimbang dan dibagi menjadi 2 tempat. Gunakan pelarut aquabidest $8 \mathrm{~L}$ untuk tujuan ekstraksi, serbuk yang sudah dipisahkan menjadi 400 gram perbagiannya diberikan larutan masing masing $4 \mathrm{~L}$ aquabidest. Kemudian diaduk dan ditutup rapat menggunakan alumunium foil. Biarkan selama 7 hari namun dipantau setiap hari dan diaduk satu kali sehari. Di hari ke 7 dilakukan penyaringan menggunakan saringan whatman no.1.

\section{Pembuatan Konsentrasi}

Dibagi dalam 4 konsentrasi :

1. Konsentrasi ekstrak jeruk limau $25 \%$ Konsentrasi ekstrak jeruk limau 25\% diambil dari 12,5ml lalu dicampurkan kedalam $87,5 \mathrm{ml}$ air lalu diletakan di wadah piring petri

2. Konsentrasi ekstrak jeruk limau $50 \%$ Konsentrasi ekstrak jeruk limau 50\% diambil dari $25 \mathrm{ml}$ lalu dicampurkan kedalam $75 \mathrm{ml}$ air lalu diletakan di wadah piring petri

3. Konsentrasi ekstrak jeruk limau $75 \%$ Konsentrasi ekstrak jeruk limau 75\% diambil dari 37,5ml lalu dicampurkan kedalam $62,5 \mathrm{ml}$ air lalu diletakan di wadah piring petri

4. Konsentrasi ekstrak jeruk limau $100 \%$ Konsentrasi ekstrak jeruk limau 100\% diambil dari $50 \mathrm{ml}$ lalu dicampurkan kedalam $50 \mathrm{ml}$ air lalu diletakan di wadah piring petri

\section{Inkubasi Larva Nyamuk Aedes Aegypti}

Larva nyamuk di beli di Laboratorium Universitas Sumatera Utara dan di inkubasi di Laboratorium Mikrobiologi Universitas Prima Indonesia.

\section{Langkah - langkah Penelitian}

1. Persiapkan 5 wadah piring petri berisikan masing masing 20 larva nyamuk didalamnya

2. Beri label untuk menandai tingkatan konsentrasi ekstrak 0\%, 25\%, 50\%, 75\%, dan 100\% 
3. Siapkan ekstrak dengan tingkatan konsentrasi ekstrak 0\%, 25\%, 50\%, 75\%, dan 100\%

4. Tuang ekstrak kedalam masing masing piring petri yang sudah sesuai dengan label konsentrasi ekstrak 0\%, 25\%, 50\%, 75\%, dan $100 \%$

5. Tingkatan ekstrak $0 \%$ hanya sebagai konsentrasi kontrol pembanding saja.

6. Amati selama 0 Menit, 30 Detik, 1 Menit, 5 Menit, 15 Menit, 30 Menit, 60 Menit, 90 Menit dan 120 Menit

7. Percobaan dilakukan sebanyak tiga kali pengulangan.

\section{Analisis data}

Analisis data yang digunakan untuk uji statistika dengan menggunakan Analisis of Variance (ANOVA) dengan menggunakan program Statistical Product and Service Solutions (SPSS) ${ }^{(6)}$. Kemudian dilanjutkan dengan menggunakan uji MannWhitney untuk melihat perbedaan antara kelompok yang bermakna dan tidak bermakna.

\section{HASIL}

Penelitian ini dilakukan di laboratorium Mikrobiologi Universitas Prima Indonesia pada tanggal pada tanggal 30 Juni 2020 sampai dengan 10 Juli 2020. Dari Hasil penelitian dan uji statistic, dapat dilihat bahwa konsentrasi ekstrak dan jangka waktu pemajanan merupakan dua faktor penting yang menentukan persentase mortalitas larva nyamuk. Semakin tinggi konsentrasi ekstrak dan waktu pemajanan, semakin tinggi persentase mortalitas larva nyamuk. Pola tersebut dapat terlihat pada gambar di bawah.

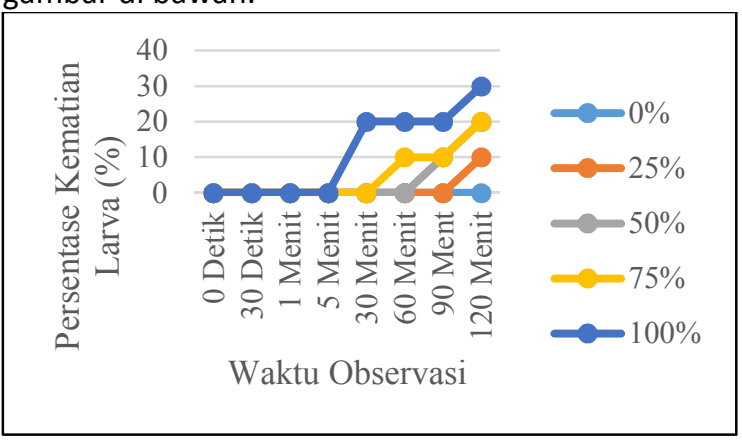

Gambar 1 Diagram Garis Hubungan antara Persentase Kematian Larva Aedes aegypti dan Konsentrasi Ekstrak Etanol Citrus amblycarpa

\section{Analisa Normalitas Data}

Sebelum dilakukan uji hipotesa, data persentase kematian larva dianalisa normalitas data dengan menggunakan uji Shapiro-wilk. Hasil analisa tersebut ada pada tabel berikut.
Tabel 1 Hasil Analisa Normalitas Data Persentase Kematian Larva Aedes aegypti oleh Ekstrak Etanol Kulit Jeruk Citrus amblycarpa.

\begin{tabular}{|c|c|c|c|}
\hline $\begin{array}{c}\text { Waktu } \\
\text { Observasi }\end{array}$ & Konsentrasi & $\begin{array}{c}\text { Nilai } \\
\text { P }\end{array}$ & Interpretasi \\
\hline \multirow{5}{*}{60 Menit } & $0 \%$ & - & - \\
\hline & $25 \%$ & - & - \\
\hline & $50 \%$ & - & - \\
\hline & $75 \%$ & 1.000 & $\begin{array}{c}\text { Terdistribusi } \\
\text { Normal }\end{array}$ \\
\hline & $100 \%$ & - & - \\
\hline \multirow{6}{*}{90 menit } & $0 \%$ & - & - \\
\hline & $25 \%$ & - & - \\
\hline & $50 \%$ & 1.000 & $\begin{array}{c}\text { Terdistribusi } \\
\text { Normal }\end{array}$ \\
\hline & $75 \%$ & $<$ & $\begin{array}{c}\text { Terdistribusi } \\
\text { Tidak }\end{array}$ \\
\hline & & & Normal \\
\hline & $100 \%$ & $\begin{array}{c}< \\
0.05\end{array}$ & $\begin{array}{c}\text { Terdistribusi } \\
\text { Tidak } \\
\text { Normal }\end{array}$ \\
\hline \multirow{5}{*}{120 menit } & $0 \%$ & - & - \\
\hline & $25 \%$ & - & - \\
\hline & $50 \%$ & $\begin{array}{c}< \\
0.05\end{array}$ & $\begin{array}{c}\text { Terdistribusi } \\
\text { Tidak } \\
\text { Normal }\end{array}$ \\
\hline & $75 \%$ & $\begin{array}{c}< \\
0.05\end{array}$ & $\begin{array}{c}\text { Terdistribusi } \\
\text { Tidak } \\
\text { Normal }\end{array}$ \\
\hline & $100 \%$ & $\begin{array}{c}< \\
0.05\end{array}$ & $\begin{array}{c}\text { Terdistribusi } \\
\text { Tidak } \\
\text { Normal }\end{array}$ \\
\hline
\end{tabular}

Dari data tabel di atas dapat dilihat bahwa dari masing-masing waktu observasi pada masingmasing konsentrasi ekstrak yang diuji menunjukkan data persentas kematian larva aedes aegypti terdistribusi tidak normal. Meskipun, pada salah satu konsentrasi uji saat waktu observasi menit ke90 menunjukkan data terdistribusi normal, namun konsentrasi lainnnya pada periode waktu yang sama menunjukkan distribusi tidak normal. Sehingga, uji hipotesa yang digunakan pada penelitian ini adalah analisa non-paramterik berupa Kruskall-Wallis dan diikuti oleh Mann-Whitney Test. 
Tabel 2 Hasil Analisa Kruskall-Wallis antara Konsentrasi terhadap Persentase Kematian Larva dari Ekstrak Etanol Kulit Jeruk.

\begin{tabular}{|c|c|c|c|c|c|c|}
\hline \multirow{2}{*}{$\begin{array}{l}\text { Waktu } \\
\text { Observa } \\
\text { si }\end{array}$} & \multicolumn{5}{|c|}{ Konsentrasi [Median] } & \multirow{2}{*}{$\begin{array}{l}\text { Nilai } \\
\text { P }\end{array}$} \\
\hline & $0 \%$ & $25 \%$ & $50 \%$ & $75 \%$ & $100 \%$ & \\
\hline 0 Detik & $\begin{array}{l}0 \\
(0) \\
\end{array}$ & $\begin{array}{l}0 \\
(0) \\
\end{array}$ & $0(0)$ & $0(0)$ & $\begin{array}{l}0 \\
(0) \\
\end{array}$ & $\begin{array}{l}1.00 \\
0\end{array}$ \\
\hline 30 Detik & $\begin{array}{l}0 \\
(0) \\
\end{array}$ & $\begin{array}{l}0 \\
(0)\end{array}$ & $0(0)$ & $0(0)$ & $\begin{array}{l}0 \\
(0)\end{array}$ & $\begin{array}{l}1.00 \\
0\end{array}$ \\
\hline 1 Menit & $\begin{array}{l}0 \\
(0) \\
\end{array}$ & $\begin{array}{l}0 \\
(0) \\
\end{array}$ & $0(0)$ & $0(0)$ & $\begin{array}{l}0 \\
(0) \\
\end{array}$ & $\begin{array}{l}1.00 \\
0 \\
\end{array}$ \\
\hline 5 Menit & $\begin{array}{l}0 \\
(0)\end{array}$ & $\begin{array}{l}0 \\
(0)\end{array}$ & $0(0)$ & $0(0)$ & $\begin{array}{l}0 \\
(0) \\
\end{array}$ & $\begin{array}{l}1.00 \\
0\end{array}$ \\
\hline $\begin{array}{l}30 \\
\text { Menit }\end{array}$ & $\begin{array}{l}0 \\
(0) \\
\end{array}$ & $\begin{array}{l}0 \\
(0) \\
\end{array}$ & $0(0)$ & $0(0)$ & $\begin{array}{l}20 \\
(0) \\
\end{array}$ & $\begin{array}{l}0.00 \\
7 \\
\end{array}$ \\
\hline $\begin{array}{l}60 \\
\text { Menit }\end{array}$ & $\begin{array}{l}0 \\
(0)\end{array}$ & $\begin{array}{l}0 \\
(0)\end{array}$ & $0(0)$ & $\begin{array}{l}10 \\
(20)\end{array}$ & $\begin{array}{l}20 \\
(0)\end{array}$ & $\begin{array}{l}0.02 \\
1\end{array}$ \\
\hline $\begin{array}{l}90 \\
\text { Menit }\end{array}$ & $\begin{array}{l}0 \\
(0)\end{array}$ & $\begin{array}{l}0 \\
(0)\end{array}$ & $\begin{array}{l}10 \\
(20)\end{array}$ & $\begin{array}{l}10 \\
(10)\end{array}$ & $\begin{array}{l}20 \\
(10 \\
)\end{array}$ & $\begin{array}{l}0.02 \\
4\end{array}$ \\
\hline $\begin{array}{l}120 \\
\text { Menit }\end{array}$ & $\begin{array}{l}0 \\
(0)\end{array}$ & $\begin{array}{l}10 \\
(0)\end{array}$ & $\begin{array}{l}20 \\
(20)\end{array}$ & $\begin{array}{l}20 \\
(10)\end{array}$ & $\begin{array}{l}30 \\
(10 \\
)\end{array}$ & $\begin{array}{l}0.01 \\
4\end{array}$ \\
\hline
\end{tabular}

Dari data tabel di atas dapat dilihat bahwa pemberian ekstrak etanol kulit jeruk menyebabkan kematian terhadap larva nyamuk setelah 30 menit pemberian ekstrak. Setelah 30 menit pemberian ekstrak, variasi konsentrasi dari ekstrak menunjukkan perbedaan yang signifikan terhadap persentase larva yang mati pada masing-masing waktu observasi, hal ini tercermin dari nilai $\mathrm{P}<0.05$. Kecenderungan persentase kumulatif dari kematian larva setelah 120 menit pemberian ekstrak terlihat paling tinggi pada konsentrasi tertinggi (100\%) dimana persentase kematiannya adalah 30\% dan pada paling rendah pada konsentrasi $25 \%$ yang hanya $10 \%$. Analisa kemudian dilanjutkan dengan Mann-whitney untuk menilai perbedaan persentase kematian larva antar konsentrasi. Analisa tersebut dilakukan pada data persentase kematian di atas 30 menit setelah observasi. Hasil analisa tersebut dapat dilihat pada tabel-tabel berikut.
Tabel 3 Hasil Analisa Mann-Whitney terhadap Masing-Masing Konsentrasi Ekstrak Etanol Kulit Jeruk Citrus amblycarpa pada 30 menit Setelah Pemberian Ekstrak.

\begin{tabular}{|c|c|c|c|c|c|}
\hline \multicolumn{2}{|c|}{$0 \%$} & $25 \%$ & $50 \%$ & $75 \%$ & $100 \%$ \\
\hline $0 \%$ & - & - & - & - & $0.025^{*}$ \\
\hline $25 \%$ & - & - & - & - & $0.025^{*}$ \\
\hline $50 \%$ & - & - & - & - & $0.025^{*}$ \\
\hline $75 \%$ & - & - & - & - & $0.025 *$ \\
\hline $100 \%$ & $0.025 *$ & $0.025^{*}$ & $0.025^{*}$ & 0.025 & 5* \\
\hline
\end{tabular}

*Terdapat perbedaan yang signfikan

Dari data tabel di atas dapat dilihat bahwa setelaah 30 menit pemberian ekstrak dijumpai perbedaan yang signifikan pada persentase larva yang mati pada konsentrasi $100 \%$ terhadap konsentrasi lainnya. Hal ini terlihat dari nilai $\mathrm{P}<0.05$ (Nilai $P=0.025$ ). Kemudian, analisa dilanjutkan terhadap waktu observasi 60 menit setelah pemberian ekstrak. Hasil analisa tersebut dapat dilihat pada tabel berikut.

Tabel 4 Hasil Analisa Mann-Whitney terhadap Masing-Masing Konsentrasi Ekstrak Etanol Kulit Jeruk Citrus amblycarpa pada 60 menit Setelah Pemberian Ekstrak.

\begin{tabular}{llllll}
\hline & $0 \%$ & $25 \%$ & $50 \%$ & $75 \%$ & $100 \%$ \\
\hline $0 \%$ & - & - & - & 0.121 & $0.025^{*}$ \\
\hline $25 \%$ & - & - & - & 0.121 & 0.121 \\
\hline $50 \%$ & - & - & - & 0.121 & $0.025^{*}$ \\
\hline $75 \%$ & 0.121 & 0.121 & 0.121 & - & 0.121 \\
\hline $\begin{array}{l}100 \\
\%\end{array}$ & $0.025^{*}$ & 0.121 & $0.025^{*}$ & 0.121 & - \\
\hline
\end{tabular}

*Terdapat perbedaan yang signfikan

Dari data tabel di atas dapat dilihat bahwa setelah 60 menit pemberian ekstrak kosentrasi tertinggi yaitu $100 \%$ terjadi perubahan yang signifikan persentase larva yang mati jika dibandingkan dengan konsentrasi 50\% dan 0\%, hal ini terlihat dari nilai $\mathrm{P}<0.05$ (Nilai $\mathrm{P}=0.025$ ). Pola kematian larva pada 60 menit setelah pemberian eksktrak menunjukkan bahwa peningkatan konsentrasi yang kecil tidak memberikan perubahan yang signifikan terhadap persentase larva yang mati, namun dengan peningkatan konsentrasi lebih besar dapat menunjukkan perubahan yang signifikan terhadap persentase larva yang mati. Analisa kemudian dilanjutkan lagi pada waktu observasi 90 menit. Hasil analisa tersebut dapat dilihat pada tabel berikut. 
Tabel 5 Hasil Analisa Mann-Whitney terhadap Masing-Masing Konsentrasi Ekstrak Etanol Kulit Jeruk Citrus amblycarpa pada 90 menit Setelah Pemberian Ekstrak.

\begin{tabular}{llllll}
\hline & $0 \%$ & $25 \%$ & $50 \%$ & $75 \%$ & $100 \%$ \\
\hline $0 \%$ & - & - & $\begin{array}{l}0.12 \\
1\end{array}$ & $\begin{array}{l}0.034 \\
*\end{array}$ & $\begin{array}{l}0.034 \\
*\end{array}$ \\
\hline $25 \%$ & - & - & $\begin{array}{l}0.12 \\
1\end{array}$ & $\begin{array}{l}0.034 \\
*\end{array}$ & $\begin{array}{l}0.034 \\
*\end{array}$ \\
\hline $50 \%$ & 0.121 & 0.121 & - & 0.637 & 0.105 \\
\hline $75 \%$ & $\begin{array}{l}0.034 \\
*\end{array}$ & $\begin{array}{l}0.034 \\
*\end{array}$ & $\begin{array}{l}0.63 \\
7\end{array}$ & - & 0.99 \\
\hline 100 & 0.034 & 0.034 & 0.10 & 0.99 & - \\
\hline & $*$ & $*$ & 5 & & \\
\hline
\end{tabular}

*Terdapat perbedaan yang signfikan

Dari data tabel di atas dapat dilihat bahwa pada konsentrasi rendah yaitu 0-25\% tidak dijumpai perbedaan persentase kumulatif kematian larva. Sama hal seperti pada konsentrasi $75-100 \%$. Namun jika dibandingkan antara konsentrasi 75-100\% terhadap kosentrasi antara $0 \%$ dan $25 \%$ dijumpai perbedaan signifikan, terlihat dari nilai $\mathrm{P}<0.05$ (Nilai $P=0.034)$. Sehingga dapat dilihat bahwa konsentrasi 75-100\% memeiliki efek larvatisida yang lebih poten daripada konsentarsi lebih kecil. Kemudian, analisa mann-whitney dilanjutkan pada waktu observasi terakhir. Hasil analisa tersebut dapat dilihat di bawah ini.

Tabel 6 Hasil Analisa Mann-Whitney terhadap Masing-Masing Konsentrasi Ekstrak Etanol Kulit Jeruk Citrus amblycarpa pada 120 menit Setelah Pemberian Ekstrak.

\begin{tabular}{|c|c|c|c|c|c|}
\hline & $0 \%$ & $25 \%$ & $50 \%$ & $75 \%$ & $100 \%$ \\
\hline $0 \%$ & - & $\begin{array}{l}0.025 \\
*\end{array}$ & $\begin{array}{l}0.034 \\
*\end{array}$ & $\begin{array}{l}0.034 \\
*\end{array}$ & $\begin{array}{l}0.034 \\
*\end{array}$ \\
\hline $25 \%$ & $\begin{array}{l}0.025 \\
*\end{array}$ & - & $\begin{array}{l}0.034 \\
*\end{array}$ & 0.114 & 0.114 \\
\hline $50 \%$ & $\begin{array}{l}0.034 \\
*\end{array}$ & $\begin{array}{l}0.034 \\
*\end{array}$ & - & $\begin{array}{l}0.034 \\
*\end{array}$ & 0.361 \\
\hline $75 \%$ & $\begin{array}{l}0.034 \\
*\end{array}$ & 0.114 & $\begin{array}{l}0.034 \\
*\end{array}$ & - & $\begin{array}{l}0.043 \\
*\end{array}$ \\
\hline $\begin{array}{l}100 \\
\%\end{array}$ & $\begin{array}{l}0.034 \\
*\end{array}$ & 0.114 & 0.361 & $\begin{array}{l}0.043 \\
*\end{array}$ & - \\
\hline
\end{tabular}

*Terdapat perbedaan yang signfikan

Dari data tabel di atas dapat dilihat bahwa variasi konsentrasi memberikan perbedaan persentase larva yang mati secara signifikan pada 120 menit setelah pemberian ekstrak, hal ini terlihat dari nilai $\mathrm{P}$ antara konsentrasi $0 \%$ terhadap konsentrasi lainnya dimana nilai $<0.05$. Sementara itu, dari data dapat adanya peningkatan konsentrasi sebesar $25 \%$ telah menunjukkan perubahan yang signifikan pada persentase larva yang mati, namun peningkatan konsentrasi yang lebih besar tidak memberikan perubahan yang signifikan pada jumlah larva yang mati.

\section{DISKUSI}

Hasil penelitian ini menunjukkan bahwa terdapat perbedaan yang signifkan pada persentase larva yang mati setelah 30 menit pemberian ekstrak etanol kulit jeruk limau (Nilai $P=0.007$ ), begitu juga setelah 60 menit (Nilai $P=0.021$ ), 90 menit (Nilai $P=$ 0.024), dan 120 menit (Nilai $P=0.014$ ). Sehingga, hipotesa alternatif yang telah dirumuskan sebelumnya diterima yaitu ekstrak etanol kulit jeruk limau memiliki efek larvatisida terhadap larva Aedes aegypti. Dengan diterimanya hipotesa alternatif ini maka, telah tercapai tujuan dalam penelitian ini yaitu untuk mengetahui efek dari ekstrak limau terhadap larva nyamuk Aedes aegypti sebagai tujuan umum, sedangkan tujuan khusus dalam penelitian ini untuk mengetahui tingkat toksisitas ekstrak jeruk limau terhadap waktu dan konsentrasi yaitu pada konsentrasi tertinggi yaitu $100 \%$ setelah 30 menit pemberian ekstrak. Efek larvatisida yang dimiliki oleh ekstrak etanol kulit jeruk citrus amblycarpa disebabkan karena kandungan berbagai fitokimia pada ekstrak etanol kulit jeruk citrus amblycarpa ${ }^{(7)}$. Kandungan fitokimia tersebut adalah kandungan flavonoid, alkaloid, serta $\operatorname{tanin}^{(8)}$.

Tanin pada ekstrak etanol Citrus amblycarpa dapat mengganggu proses penyerapan makanan pada serangga ${ }^{(9)}$, dimana tanin akan mengikat protein-protein pada saluran cerna sehingga menggangu proses pertumbuhan larva. Sama halnya sepeti tanin flavonoid juga mengikat protein disaluran cerna, selain itu flavonoid juga mengganggu struktur protein pada permukaan sel sehingga menggangu permeabilitas sel sehingga dapat memperberat kerusakan pada sel-sel larva. Terakhir kandungan alkaloid juga berperan dalam efek larvatisida dari ekstrak etanol amblycarpa karena Alkaloid dapat mengganggu sistem kerja dari saraf, menghambat daya makan, dan sebagai racun perut pada larva nyamuk. ${ }^{(10)}$

\section{SIMPULAN}

Adapun kesimpulan dari penelitian ini adalah sebagai berikut:

1. Dibutuhkan waktu setidaknya 30 menit agar ekstrak etanol kulit jeruk Citrus amblycarpa dapat memberikan efek larvaticida pada larva nyamuk aedes aegypti.

2. Pada waktu observasi awal dibutuhkan perubahan konsentrasi yang besar untuk menunjukkan perbedaan yang signifikan 
terhadap persentase larva yang mati. Namun, seiring dengan peningkatan waktu observasi, dibutuhkan perubahan konsentrasi yang kecil untuk menunjukkan perbedaan yang signifikan terhadap persentase larva yang mati.

3. Memiliki perbedaan yang signifikan pada presentase mortalitas larva nyamuk aedes aegypti yang diberikan ekstrak jeruk limau dan kelompok kontrol.

4. Tingkat konsentrasi ekstrak berpengaruh dalam presentase mortalitas larva nyamuk aedes aegypti.

5. Lamanya waktu uji berpengaruh dalam presentase mortalitas larva nyamuk aedes aegypti

\section{SARAN}

1. Perlu dilakukan penelitian lebih lanjut untuk membandingkan efek larvatisida dari bagian lain dari jeruk Citrus amblycarpa.

2. Perlu dilakukan penelitian lebih lanjut untuk membandingkan efek larvatisida dari beberapa metode ekstraksi dari kulit jeruk Citrus amblycarpa.

3. Perlu dilakukan pengujian lebih lanjut dengan menggunakan etanol mengenai uji toksisitas ekstrak jeruk limau (citrus amblycarpa) terhadap larva nyamuk

4. Perlu dilakukan pengujian terhadap hewan serangga dengan menggunakan esktrak jeruk limau (citrus amblycarpa) dengan kasus yang sama.

5. Perlu dilakukan pengujian lebih lanjut dengan ekstrak yang berbeda terhadap larva nyamuk aedes aegypti.

6. Butuh pengujian efek toksisitas flavonoid, alkaloid dan tanin yang diisolasi dari jeruk limau pada mortalitas larva nyamuk.

\section{DAFTAR PUSTAKA}

1. Adrianto $\mathrm{H}$, Yotopranoto S. Efektivitas Ekstrak Daun Jeruk Purut (Citrus Hystrix), Jeruk Limau (Citrus Amblycarpa), Dan Jeruk Bali (Citrus Maxima) Terhadap Larva Aedes Aegypti.

2. Liza. Arthropod-Borne Virus, genus Flavivirus, Demam Berdarah Dengue. 2016;2009(4):1-8.

3. Karyanti $M$, Hadinegoro $S$. Perubahan Epidemiologi Demam Berdarah Dengue Di Indonesia. Sari Pediatr. 2016 Nov 29;10:424.

4. Muwawi Siregar. Perilaku Masyarakat dalam Pemberantasan Sarang Nyamuk dengan Menguras, Menutup dan Mengubur (3M) serta Faktor yang Mempengaruhinya di Kelurahan Cirendeu RW.09 Tahun 2011. 2011; Available from:

http://repository.uinjkt.ac.id/dspace/handle/1 23456789/34216

5. Fitrianda MI. Digital Digital Repository Repository Universitas Universitas Jember Jember Digital Digital Repository Repository Universitas Universitas Jember. 2013;

6. Romas A. Uji Aktivitas Antibakteri Ekstrak Etanol Kulit Buah Manggis (Garcinia mangostana I) Terhadap Bakteri Escherichia coli ATCC 11229 DAN Staphylococcus aureus ATCC 6538 Secara In Vitro. Univ Res Colloq 2015. 2015; ISSN 2407-:127-32.

7. Khasanah LU. Pengaruh Perlakuan Pendahuluan terhadap Karakteristik Mutu Minyak Atsiri Daun Jeruk Purut (Citrus hystrix DC). J Apl Teknol Pangan. 2015;04(02):48-55.

8. Maharani RAIK, Cahyaningsih NK, Abimanyu MD, Astuti KW. Kulit Buah Jeruk Limau (Citrus amblycarpa (Hassk.) Osche) Sebagai Analgesik. J Kim. 2020;14(1).

9. Ishak NI. Efektifitas Perasan Buah Limau Kuit (Citrus amblycarpa) SEBAGAI Larvasida Alami Terhadap Kematian Larva Aedes aegypti ) The Effectiveness of Juice of Limes Kuit (Citrus amblycarpa) as Natural Larvasides Against Death of Aedes Aegypti larvae. 2020;10:6-13.

10. Edra Esy; Nugraha, Dimas $P$ AM. The comparison of larvacidal effects of ethanol extract of cinnamon (Cinnamomum burmanni) and temephos against Aedes aegypti mosquitoes. J Online Mhs Bid Kedokt. 2014;1(2):1-11. 